\title{
Gender Bias at the Brazilian Superior Labor Court*
}

\author{
Stefânia Grezzana** \\ Vladimir Ponczek ${ }^{* * *}$
}

\begin{abstract}
This paper examines the existence of gender bias within the Brazilian Superior Labor Court SLC(TST). Our analysis utilizes a database comprising all the lawsuits decided by the Brazilian Superior Labor Court SLC(TST) between August 2008 and June 2009. We explore, in particular, the fact that the lawsuits are randomly distributed among the judges (male or female) to analyze if the Reporting Judge's gender has an impact over the result of the lawsuit depending on the worker's gender. The results indicated that if we do not condition on nature of the lawsuit, the judges are not gender-biased. However, when we consider the type of lawsuit to be decided, we noticed that, as to some causes, such as: "salary equalization", "framing and affiliations", female judges tend to favor female individuals, whereas male judges are bent to favor male individuals. Our study enhances a possible institutional mechanism that may, at least, explain part of the salary differential between the genders.
\end{abstract}

Keywords: Labor Justice, Gender Bias.

JEL Codes: J16, D02.

\footnotetext{
${ }^{*}$ Submitted in March 2013. Revised in April 2013. We thank the commentaries and valuable suggestions made by the Editor and the anonymous referees which highly contributed to the improvement of this work. All the remaining errors are ours. Finally, Stefânia Grezzana thanks the financial aid received by CAPES/Brazil.

${ }^{* *}$ São Paulo School of Economics - FGV, Brazil. E-mail: stefania.grezzana@fgv.br

*** São Paulo School of Economics - FGV and C-Micro, Brazil. E-mail: vladimir.ponczek@ fgv.br
} 


\section{Introduction}

This paper aims at investigating the presence of gender bias within the Brazilian labor justice, particularly in the sphere of the Brazilian Superior Labor Court SLC(TST). The relevance of this study brings about the fact that the existence of gender bias inside the Brazilian labor justice may be one additional mechanism that causes a salary gender bias.

In several other countries there is a significant differential between men and women in the principal variables related to the labor market (see Gender Gap Report, 2012). The empirical literature shows that such differences persist even after being controlled by different attributes such as: education, family background, race, age, etc. (see Blau and Kahn (1997); Bertrand and Hallock (2001); Albrecht et al. (2003); Bayard et al. (2003); Bucheli and Sanroman (2005); Galarza et al. (2006); Madalozzo and Martins (2007); Olivetti and Petrongolo (2008)).

The leading explanations attributed to the salary differential per gender lie in differences as to productivity, gender discrimination or institutional questions. The first case comprehends cultural factors, decisions on life cycle or activity sector what would make women less productive than men. The factors related to this first explanation are linked to the constant transitions as to joining and leaving the labor market what happens to women during their productive life cycle (see Deloach and Hoffman (2002); Hersch and Stratton (2002); Moe (2003); Blau et al. (2006); Bryan and Sanz (2007)). Women are more often prone to becoming involved in family and home activities than men due to cultural reasons (see Hersch and Stratton (1994); Álvares and Miles (2006); Lundberg (2008); Madalozzo et al. (2010); Gupta and Ash (2008)). Men may also choose riskier sectors and activities that pay more through countervailing mechanisms. In the second case, the discrimination based on the preference against women may make it difficult for women to hold certain positions or determine lower salaries compared to those paid to men for the same positions (see Easterlin (1995); Macpherson and Hirsch (1995); Miller (2009)).

The third explanation concerns institutional factors linked to the labor market regulation that may convey differentiated benefits to men and women such as: maternity leave (see Waldfogel (1998); Edwards (2006); Bergmann (2008)). In this case, such differences may impact over salaries, which could explain at least part of the salary differential between genders. Our paper lies in this third group as we investigate the existence of a labor justice behavior that may cause direct effects over the salary differential between men and women.

On the whole, the influence of the labor justice over the workers' salaries and earnings may happen in different ways. Firstly, when they define the jurisprudence concerning the employer's obligation to pay some benefits to the employee, the justice generate, in equilibrium, direct impacts over the workers' salaries. Secondly, when they invalidate private labor contracts that in some ways make it more flexible the requirements of the labor legislation, the justice may also affect the 
salaries in equilibrium. The literature has already analyzed and registered the effect of the labor justice legislation over the workers' salaries of equilibrium (see, for instance, Heckman and Pagés (2000); Araújo and Ponczek (2012)). Thus, different decisions for men and women may produce heterogeneous results as to genders in the labor market.

It is wise to point out that the simple substantiation that the Brazilian justice decides unequally between men and women cannot be characterized as a gender bias. The labor legislation usually treats men and women in a different manner. These differences in the legislation (example: maternity leave, minimum age for retirement, etc.) have already been examined by the literature that shows consequences to the labor market as to women. Our study envisages the investigation of the differences in dealing with men and women that are beyond the legislation. Our interest is to study, conditioned on the ruling legislation, to what extent judicial decisions are influenced by the worker's gender. The difficulty of this exercise lies in the causal identification of this exclusive bias within the judicial decision isolating it from the decision arising from the heterogeneity of the legislation. To this extent, we need variations in judicial decisions that do not depend on the differential treatment granted by the labor legislation. In this connection, we investigate if the judge's personal characteristics interfere with his own decision depending on the worker's gender. More specifically, we analyze if the judge's gender interferes with his decision depending if the worker is a man or a woman. Considering this heterogeneity arising from the judge's gender, a labor court with a higher or lower number of female judges would undoubtedly produce a bias independent of the legislation itself once the legislation does not differ the judge's gender.

For this purpose, we analyzed all the Superior Labor Court SLC(TST) decisions from August 2008 to June 2009. We take advantage of the fact that the lawsuits distribution among the judges is randomly assigned, therefore it is not possible for a judge to choose the lawsuit based on the worker's gender or any other trait concerning the people involved or the lawsuit. At first, we examined if the worker's gender influences, in a different way, male and female judges at the Superior Labor Court SLC(TST) no matter what kind of case it is. Later on, we conditioned the analysis to decisions containing a more specific nature with the purpose of investigating if certain kinds of cases are more prone to a bias on the part of the judges.

It is wise to point out that our exercise does not allow us to identify the cause of the gender bias. The existence of discrepancies about certain decisions due to the participant's gender or the judge's may arise from a major knowledge of the judges as to the necessities and preferences of the individuals of their own gender and not necessarily due to a discriminatory behavior. For example, possibly female Judges from the Superior Labor Court might be more inclined to favor women than men because they have a better understanding concerning the female gender's demands and behavior. Literature has already illustrated such biased behavior in other 
situations. For instance, Chattopadhyay and Duflo (2004) show that when women assume political governance assignments, the kind of public policy adopted by them tends to meet more often the women's needs.

In any case, the existence of gender bias within the labor justice independent of the cause, originates direct consequences onto the labor market and this bias finding may be useful to the elaboration and implementation of public policies aiming at reducing the salary differential between genders.

The results indicate that even if the bias is not present in all the types of causes and that, on the whole, it does not play a significant role in the general lawsuits results, some decisions carrying a specific nature, such as: "equalization", "framing and affiliation", and "other cases" present a component of a significant bias according to our results. In these cases there would be a favoring by the female judges in relation to the female parts and the male judges in relation to the male parts.

The remaining of our paper is divided into: Section 2 shows how the Superior Labor Court operates, its jurisdiction and the individuals' organization in the judicial bodies. Section 3 describes the data base; in Section 4 we present the methodology used; Section 5 covers the documentation and the interpretation of the empirical results; Section 6 concludes the paper.

\section{The Superior Labor Court Operation}

As our paper analyzes the decision-making process of the Judges of the Brazilian Superior Labor Court, it is of paramount importance to present a basic overview on how the Court operates as well as its tasks.

The Superior Labor Court SLC(TST) whose decisions will be analyzed in this paper, represents the Labor Justice extraordinary resort. The choice of the judges that constitute the Superior Labor Court SLC(TST) is made according to article 111-A of the constitutional amendment number 45 November 30/2004:

Art. 111th - A The Superior Labor Court consists of twenty-seven judges chosen among Brazilians aged more than thirty-five years and less than sixty-five appointed by the President of the Republic after being approved by the absolute majority of the Federal Senate, considering: I one fifth among lawyers having more than ten years of effective professional experience and members of the Public Labor Ministry having more than ten years of effective activity observing what is disposed in art. $94 ;^{1}$ II the remaining judges among the Regional Labor Courts,

${ }^{1}$ Article 94 of the Federal Constitution provides: "Art.94 - One fifth of the seats of the Regional Federal Courts, the State Courts, the Federal District Courts and Territories will consist of members from the Public Ministry having more than ten years of activity and lawyers holding a noteworthy legal knowledge and having a flawless reputation with more than ten years of effective professional activity appointed by the representative class members through a sextuple list" (Federal Constitution 1988). 
coming from the bench career appointed by the Superior Court itself (Constitutional Amendment, n. 45, 2004).

The President will select, from a triple list elaborated by the Superior Labor Court SLC(TST) members, the one chosen to take over the Judge's position and the appointment is submitted to the Federal Senate.

The SLC(TST) panels consist of three judges each one and they are chaired by the panel's senior member, but for the trial to take place the presence of the three judges is mandatory. In our paper, we will attribute a higher importance to the panels, because even if a Judge wishes to join a certain Panel, he will not be allowed to know the lawsuit nature. Therefore, we maintain the lawsuits randomization effect so important to the accomplishment of this study.

It is up to the Superior Labor Court's panels to judge the appealed motions to review applied against the Regional Labor Courts decision in the cases established by law; the interlocutory appeals of orders from the Regional Labor Courts that deny the follow-up to a point of law; the ordinary appeals and the appeals against court regulations applied against order issued in lawsuits of its jurisdiction; and the ordinary appeals in writs of prevention when the jurisdiction for judging the appeal of the principal lawsuit is attributed to the Panel.

Finally, it is of paramount importance in our paper the fact that the proceedings are randomly distributed among the judges in all the jurisdictions of the Brazilian Labor Justice. Thus, it is not up to the judge to choose the kind of case that he prefers to judge and not even the lawyer is allowed to file a suit in the court (1st jurisdiction) where his favorite judge acts.

\section{Database}

The database of this paper comprehends the lawsuits analyzed by the Superior Labor Court judges from August 2008 till June 2009. Within this period 162,815 proceedings were judged.

Since our paper goal is to analyze the gender bias, we will employ only the lawsuits involving two parties in the dispute - a plaintiff and a defendant - excluding, thus, those proceedings in which more than one person jointly brought a suit. We adopted this procedure because, in this case, we might have persons with different genders on the same litigation side making it unfeasible to identify any stance of the judges in relation to the parties' gender.

Therefore, the sub-sample that involves one person (an individual, mainly a worker, or a legal entity, generally, a company) on each side of the lawsuit represents a total of 109,368 events. Furthermore, we exclude the ones whose judge's decisions were not available in the database and the remaining ones total 94,143 proceedings which constitute the principal sample of this study.

Additionally, we tried out a complementary subsample consisting of 1,904 lawsuits randomly selected from the principal sample. As to such lawsuits, we ob- 
tained their cause, that is, the motivation and the scope of the dispute. The wide diversity of causes made it necessary to aggregate them into wider categories. This aggregation was made according to the similarity of the requested themes. (See Annex 1 with each subcategory within each grouping).

The database contains information about the lawsuits - including information of both parties involved in the dispute, the kind of economic activity in which the labor relation occurred - as well as of the judges responsible for deciding about each cause.

Among the data concerning the dispute, there is information regarding the year in which the action was filed, the federation unit and the Labor Jurisdiction where the action was applied, the name of the parts involved in the dispute, if it is an individual or a legal entity, the date when the lawsuit was judged, the economic activity in which the labor relation occurred, the Reporting Judge's session code, the panel body, and the decision made in that session. This Reporting Judge's code is unique for each judge and this allows us the cross-checking with the judges' individual characteristics.

As to the Judges' profile, we have the individual traits concerning the 22 male judges and 5 female judges, such as: age, college where they obtained their degree, the legal career from where they come and the date when each one took office as a judge of the Superior Labor Court.

Finally, our interest lies in the proceeding result in relation to the individual and the variable analyzed is built having this fact in view. Thus the indicator variable (resultPF) obtains value 1 if the result of the proceeding is in favor of the individual and 0 otherwise, independent of whom appealed to the labor jurisdiction analyzed.

The descriptive statistics concerning the SLC(TST) judges show that men are the majority within the SLC(TST). Men represent more than $80 \%$ of the judges and, furthermore, their mean age is 57.41 years old (see Table 1 for the judges' descriptive statistics).

The SLC(TST) consists of a few judges and this may make the extrapolation of the results more difficult considering that it is highly unlikely that the SLC(TST) pattern of decisions be the same within the remaining labor justice. Nonetheless, we believe that the analysis remains relevant since the SLC(TST) is responsible for the elaboration of binding judicial precedents that define results of proceedings in all the jurisdictions of the Brazilian labor justice, that is, a biased behavior by the SLC(TST) judges may be extended to the whole Brazilian Labor Judiciary power even if the other jurisdictions seem unbiased. Moreover, the analyzed judges have been at the SLC(TST) for 7 years on average, but the most experienced took office 19 years ago. Thus, the presence of bias may last for as long as two decades.

Table 1 shows the descriptive characteristics of the SLC(TST) male and female judges. We noticed that, on average, the women judges are a little younger than the men judges (a little more than a year) but much less experienced (3.07 years less). 
As to their previous career, men and women are relatively well distributed, around $80 \%$ and $20 \%$ are career judges and lawyers, respectively, and only one came from the Department of Justice. When we analyzed the college institution, we noticed that, mostly, the judges graduated in public education institutions. Men judges tend to have this pattern more intensified than women judges $(77.3 \% \times 60 \%)$.

Table 1

Descriptive Statistics of Male and Female Judges of the SLC(TST)

\begin{tabular}{lcc|cc|cc}
\hline \multicolumn{7}{c}{ Characteristics of Male/Female Judges } \\
\hline & & & \multicolumn{2}{c}{ Female Judges } & \multicolumn{2}{c}{ Male Judges } \\
\hline Total of Judges & 27.00 & $\%$ & 5 & $19.23 \%$ & 22 & $81.48 \%$ \\
\hline Mean age & 57.41 & & 56.40 & & 57.64 & \\
& $(6.89)$ & & $(6.58)$ & & $(7.08)$ & \\
Over 60 years old & 9.00 & 34.62 & 1.00 & $20.00 \%$ & 8.00 & $36.36 \%$ \\
Mean of years at the SLC(TST) & 6.70 & & 4.20 & & 7.27 & \\
& $(4.56)$ & & $(2.77)$ & & $(4.74)$ & \\
Career Judges & 21.00 & 77.78 & 4.00 & $80.00 \%$ & 17.00 & $77.27 \%$ \\
Public Ministry & 1.00 & 3.85 & 0.00 & $0.00 \%$ & 1.00 & $4.55 \%$ \\
Attorneyship & 5.00 & 19.23 & 1.00 & $20.00 \%$ & 4.00 & $18.18 \%$ \\
Public Education & 20.00 & 74.07 & 3.00 & $60.00 \%$ & 17.00 & $77.27 \%$ \\
Private Education & 70.00 & 26.92 & 2.00 & $40.00 \%$ & 5.00 & $22.73 \%$ \\
\hline
\end{tabular}

Source: Brazilian Superior Labor Court SLC(TST) (Own elaboration).

Table 2 presents the descriptive statistics of the 94,143 proceedings that constitute the sample. We noticed that $97.97 \%$ of the proceedings have at least one legal entity involved - a labor union, a joint stock company, limited or any size, public or private - whereas $95.75 \%$ have at least one individual involved. Furthermore, most $(69.93 \%)$ cover proceedings that comprehend male individuals. We also noticed that most disputes involve an individual and a legal entity, specially a legal entity filling the lawsuit against an individual. A possible justification for this lies in the fact that the Superior Labor Court is, in general, the last jurisdiction of the labor proceedings where, in general, the ones that lost their disputes in the previous courts try to turn the preceding decision. If we believe that the workers are the ones who apply against their employers it is percipient that the majority $(72.47 \%)$ of the SLC(TST) proceedings have a legal entity authorship, since in most cases they are appealing to a favorable decision towards the worker obtained in the previous court.

The women judges adjudge $21.48 \%$ of the proceedings against $78.52 \%$ decided by the men judges. Moreover, judges coming from the bench, advocating career, and the prosecuting attorneys decide $78.42 \%, 19.75 \%$ and $1.83 \%$ of the proceedings respectively. Finally, among the economic activities, the services sector (predominantly), the trading business, and the industry are the activities more prone to such disputes.

The proceedings statistics show that $67.79 \%$ of the lawsuits involving an indi- 
vidual and a legal entity indicate that the individual obtains a favorable result and that only $32.21 \%$ favors the legal entity. However, the sole conclusion according to which the justice often decides in favor of the worker does not necessarily imply a bias on the part of the judges since they may be solely abiding by the labor laws that, in turn, favor the worker in relation to the employer.

Table 2

Descriptive Statistics of the Proceedings

\begin{tabular}{|c|c|c|}
\hline \multicolumn{3}{|l|}{ Descriptive Statistics of the Proceedings } \\
\hline Total of Proceedings & 94,143 & $\%$ \\
\hline Number of proceedings with Legal Entities (PJ) & 92,232 & 97.97 \\
\hline Number of Proceedings with Individuals (PF) & 90,143 & 95.75 \\
\hline Males & 24,625 & 27.32 \\
\hline Females & 63,041 & 69.93 \\
\hline Unknown Gender & 2,477 & 7.75 \\
\hline Within individual proceedings $\times$ individual proceedings & 1,911 & 2.03 \\
\hline Within legal entities proceedings $\times$ legal entities proceedings & 4 & 4.25 \\
\hline $\begin{array}{l}\text { Within Individual proceedings } \times \text { legal entities proceedings or legal entities } \times \\
\text { individual entities }\end{array}$ & 88,232 & 93.72 \\
\hline Proceedings won by the individuals & 59,809 & 67.79 \\
\hline Males & 15,643 & 26.15 \\
\hline Females & 42,082 & 70.36 \\
\hline Unknown Gender & 2,084 & 3.48 \\
\hline Proceedings lost by the individuals (PF) & 28,423 & 32.21 \\
\hline Males & 8,147 & 28.66 \\
\hline Females & 19,363 & 68.12 \\
\hline Unknown Gender & 913 & 3.21 \\
\hline Within the proceedings whose plaintiff is an Individual & 25,914 & 27.53 \\
\hline Males & 7,09 & 27.36 \\
\hline Females & 18,035 & 69.60 \\
\hline Unknown Gender & 789 & 3.04 \\
\hline Within the proceedings whose plaintiff is a legal entity & 68,229 & 72.47 \\
\hline Within the proceedings whose defendant is an individual & 66,14 & 70.25 \\
\hline Males & 17,78 & 26.88 \\
\hline Females & 45,953 & 69.48 \\
\hline Unknown Gender & 2,407 & 3.64 \\
\hline Within the proceedings whose defendant is a legal entity & 28,003 & 29.75 \\
\hline Judged by Female Judges & 20,218 & 21.48 \\
\hline Judged by Male Judges & 73,925 & 78.52 \\
\hline Judged by Lawyers & 18,595 & 19.75 \\
\hline Judged by Magistrates & 73,825 & 78.42 \\
\hline Judged by Public Prosecutors & 1,723 & 1.83 \\
\hline Economic Activity & & \\
\hline Industry & 20,148 & 21.44 \\
\hline Commerce & 23,297 & 24.79 \\
\hline Services & 42,817 & 45.56 \\
\hline Agribusiness & 5,036 & 5.36 \\
\hline Others & 2,686 & 2.86 \\
\hline
\end{tabular}

Table 3 crosses the information items regarding the Judges with the proceedings. On the whole, we noticed that the characteristics of the proceedings are fairly well distributed among the judges. About $98 \%$ of the proceedings decided - either by men judges or women judges - involve at least one legal entity. This number drops to around $96 \%$ when we look at proceedings with at least one individual 
involved. At the same time, men judges and women judges decide about $27 \%$, $70 \%$ and $3 \%$ of the proceedings involving female, male, and unknown individuals, respectively. The other characteristics also seem fairly well distributed among the genders. These proofs corroborate the fact that the proceedings are randomly distributed among the judges. Table 3 shows that the proceedings decided by men judges and women judges do not present crucial differences in their characteristics.

In relation to the proceedings results, the statistics show that the men judges bestow more favorable cases to the individual (68.69\%) than women judges $(64.67 \%)$. The data unconditional analysis shows no evidence in which the worker's gender would influence either the men judges or the women judges' decision. This result, in principle, would indicate the absence of gender bias within the SLC(TST). However, a more detailed analysis will be made in the coming sections.

\section{Empirical Strategy}

In this paper we analyzed the possibility of the existence of gender bias in the judges' decisions within the Brazilian Superior Labor Court. Consequently, we tested the hypothesis of the probability according to which the women judges would decide about the proceedings more in favor of a claimant of a certain gender than the men judges.

We employed a methodology which tries to identify the presence of bias through the interaction between the Reporting Judge's gender and that of the individual assuming that the bias occurs already in the Reporting Judge's decision. We utilized the Logit methodology as the identification strategy and we are interested in the coefficient of the variable expressing the interaction between the individual's gender and that of the Reporting Judge.

\section{Logit}

According to our classification, the proceedings result may be in favor or against the individual. Thus, we assign value 1 to our indicator variable when the result occurs in favor of the individual and 0 if conversely. Therefore our judge's decision variable is a binary variable. Accordingly, we will employ the Logit model in our regressions:

$$
\begin{aligned}
\text { resultPF }_{i} & =1\left(\alpha_{0}+\alpha_{1} d P F \text { Woman }_{i}+\alpha_{2} \text { dJudgeW }_{i}+\alpha_{3} d P F \text { Woman }_{i}\right. \\
& \left.\times \text { JudgeW }_{i}+\gamma \text { controls }_{i}+\varepsilon_{i} \geq 0\right)
\end{aligned}
$$

in which $1_{(.)}$is an indicator function; $d P F W o m a n_{i}$ is a dummy variable that assumes value 1 if the individual in the proceeding $i$ is of the female gender; $d J u d g e W_{i}$ is an indicator variable that assumes value 1 if the proceeding reporting judge $i$ is a woman judge; controls $s_{i}$ is a vector of control variables over the 
Table 3

Descriptive Statistics of the Proceedings per Judge's Gender

\begin{tabular}{|c|c|c|c|c|c|}
\hline \multicolumn{6}{|c|}{ Descriptive Statistics of the Proceedings } \\
\hline & $\begin{array}{l}\text { Judged by } \\
\text { Female }\end{array}$ & $\%$ & $\begin{array}{l}\text { Judged by } \\
\text { Male }\end{array}$ & $\%$ & $\begin{array}{c}z \text {-test of } \\
\text { the difference }\end{array}$ \\
\hline Total of Proceedings & 20,218 & 21.48 & 73,925 & 78.52 & - \\
\hline $\begin{array}{l}\text { Within Legal } \\
\text { ings }(\mathrm{PJ})\end{array}$ & 19,816 & 98.01 & 72,416 & 97.96 & 0.05 \\
\hline Within Individual Proceedings PF) & 19,395 & 95.93 & 70,748 & 95.70 & 0.14 \\
\hline Females & 5,315 & 27.40 & 19,31 & 27.29 & 0.02 \\
\hline Males & 13,571 & 69.97 & 49,47 & 69.92 & 0.01 \\
\hline Unknown Gender & 509 & 2.62 & 1,968 & 2.78 & -0.02 \\
\hline $\begin{array}{l}\text { Within Individual Proceedings } \times \text { In- } \\
\text { dividual Proceedings }\end{array}$ & 402 & 1.99 & 1,509 & 2.04 & -0.01 \\
\hline $\begin{array}{l}\text { Within Legal Entities Proceedings } \times \\
\text { Legal Entities Proceedings }\end{array}$ & 823 & 4.07 & 3,177 & 4.30 & -0.03 \\
\hline $\begin{array}{l}\text { Within Individual Proceedings } \times \text { Le- } \\
\text { gal Entities Proceedings or Legal En- } \\
\text { tities } \times \text { Individuals }\end{array}$ & 18,993 & 93.94 & 69,239 & 93.66 & 0.14 \\
\hline Proceedings won by Individuals & 12,283 & 64.67 & 47,526 & 68.64 & -0.83 \\
\hline Females & 3,198 & 26.04 & 12,445 & 26.19 & -0.02 \\
\hline Males & 8,663 & 70.53 & 33,419 & 70.32 & 0.04 \\
\hline Unknown Gender & 422 & 3.44 & 1,662 & 3.50 & -0.01 \\
\hline Proceedings lost by Individuals & 6,71 & 35.33 & 21,713 & 31.36 & 0.60 \\
\hline Females & 1,944 & 28.97 & 6,203 & 28.57 & 0.03 \\
\hline Males & 4,565 & 68.03 & 14,798 & 68.15 & -0.02 \\
\hline Unknown Gender & 201 & 3.00 & 712 & 3.28 & -0.02 \\
\hline $\begin{array}{l}\text { Within the Proceedings whose plain- } \\
\text { tiff is an Individual }\end{array}$ & 5,684 & 28.11 & 20,23 & 27.37 & 0.11 \\
\hline Females & 1,577 & 27.74 & 5,513 & 27.25 & 0.04 \\
\hline Males & 3,933 & 69.19 & 14,102 & 69.71 & -0.06 \\
\hline Unknown Gender & 174 & 3.06 & 615 & 3.04 & 0.00 \\
\hline $\begin{array}{l}\text { Within the Proceedings whose plain- } \\
\text { tiff is a Legal Entity }\end{array}$ & 14,534 & 71.89 & 53,695 & 72.63 & -0.18 \\
\hline $\begin{array}{l}\text { Within the Proceeding whose defen- } \\
\text { dant is an Individual }\end{array}$ & 14,113 & 69.80 & 52,027 & 70.38 & -0.13 \\
\hline Females & 3,787 & 26.83 & 13,993 & 26.90 & -0.01 \\
\hline Males & 9,843 & 69.74 & 36,11 & 69.41 & 0.06 \\
\hline Unknown Gender & 483 & 3.42 & 1,924 & 3.70 & -0.03 \\
\hline $\begin{array}{l}\text { Number of Proceedings whose defen- } \\
\text { dant is a Legal Entity }\end{array}$ & 6,105 & 30.20 & 21,898 & 29.62 & 0.09 \\
\hline Judged by Lawyers & 2,491 & 12.32 & 16,104 & 21.78 & \\
\hline Judged by Magistrates & 17,727 & 87.68 & 56,098 & 75.89 & \\
\hline Judged by Public Prosecutors & 0 & 0.00 & 1,723 & 2.33 & \\
\hline Economic Activities: & & & & & \\
\hline Industry & 4,412 & 21.82 & 15,736 & 21.29 & 0.08 \\
\hline Commerce & 5,155 & 25.50 & 18,142 & 24.54 & 0.14 \\
\hline Services & 9,037 & 44.70 & 33,78 & 45.69 & -0.17 \\
\hline Agribusiness & 1,043 & 5.16 & 3,993 & 5.40 & -0.03 \\
\hline Others & 571 & 2.82 & 2,115 & 2.86 & 0.00 \\
\hline
\end{tabular}

Source: Brazilian Superior Labor Court SLC(TST)(Own elaboration) 
individual, the Reporting Judge and the proceeding $i$; and $\varepsilon_{i}$ is the error term which, by hypothesis, has a logistical distribution function.

Our interest concentrates on the coefficient of the interaction variable between the individual's gender and that of the Reporting Judge. This variable captures the probability of female Judges favoring female workers relatively to male workers in relation to the probability of male Judges favoring male workers relatively to female workers, that is, it captures the bias of female Judges towards female workers visà-vis of male Judges towards male workers. The marginal effect of the independent variable over the dependent variable corresponds to the logarithm of the odds ratio that the outcome will be favorable to the individual.

\section{Results}

Table 4 reports the estimates obtained through the regression of equation(1) considering only the proceedings sample involving only one individual, no matter if it is the complainant or the defendant. In this case, 5911 proceedings were excluded $(6.279 \%)$ as there was more than one individual involved in the proceedings. Additionally, 1161 proceedings were excluded (1.233\%) because they belonged to the Special Agencies and not the SLC(TST) Panels. We exclude this proceedings because they are allocated to these agencies due to some specific characteristics, at the same time in which the judges may choose which specialized section they would like to be part of. Therefore, if we did consider such proceedings we would be discarding the randomly element of our database.

The randomization is high-priority to our analysis because it permits us to believe that the achieved effect may be classified as a gender bias. In such case, we kept only the proceedings decided by the Panels which consist of proceedings having the same nature and judged by the vast array of judges. The variables presented in the regression, are, in most cases, dummy variables (see exhibit 2 for the variables descriptions).

In the regression Equation I, we used as explanatory variables only two dummies that indicate if the individual and the Reporting Judge pertain to the female gender $d P F M W$ oman $_{i}$ e $d J u d g e W_{i}$.

Regression Equation II includes our interest variable that is the Reporting Judge's interaction with the individual's gender. The estimates of the coefficient linked to this interaction are not statistically different from zero, maintaining the pattern despite the inclusion of the control variables what, once again, suggests the non-existence of gender bias at the SLC(TST).

Conversely, Regression Equation III includes as control some characteristics of the Reporting Judges, such as age, if attended a public or private college institution, the original career, and the number of years at the SLC(TST). The regression Equation IV includes as control the country region where the judge comes from. Regression Equation V also includes the dummies regarding the President's nomination to the office. Regression Equation VI contains the dummy variable 
(dp1Individual) which shows if the party that petitioned at the SLC(TST) was an individual.

Regression Equation VII added the year when the action was filed at the first jurisdiction as a control and, finally, regression Equation VIII includes the kind of economic activity in which the job relation occurred.

The results of the regressions indicate that if the individual belongs to the female gender, the probability of winning the action is lower than when the individual belongs to the male gender and that the women judges tend to be more against the individuals (independent of the worker's gender) than the judges belonging to the male gender.

It is wise to point out an important proviso: our study limits to actions that were disputed within the SLC(TST). Most likely, several proceedings had their disposal judged by lower jurisdictions without one of the parties' appeal to the SLC(TST) or even ended up in an agreement. Thus, there is a selection on the proceedings observed in this paper. In this sense, a smaller chance of victory to female workers not necessarily means that the labor justice or the legislation is stricter to females, but it is possible that the proceedings concerning females reaching the SLC(TST) are more lenient to workers than in proceedings in which the individual belongs to the male gender.

The interaction coefficient does not show a meaningful statistical result. So, in a general sense, we cannot conclude that, unconditionally to the kind of cause, there is a gender bias as to the decisions within the SLC(TST). The results are extremely robust to the inclusion of the multiple control variables. In this case, the harmful effects over the estimator's consistency due to the possible sample selection discussed are mitigated. Our identification comes from the judge's gender variation regarding the proceeding. That is, due to the randomization, the female workers' proceedings that reach the male judges are, on average, as frail as the ones sent to the female judges. Therefore, the differential among the results for both types of Judges cannot be credited to the proceedings selection.

Aiming at eliminating the problems concerning essential differences among the proceedings, we performed an additional exercise in which we made a separate analysis of the bias considering a specific kind of cause in the proceedings. As to this exercise, we established a subsample containing 1904 proceedings, randomly chosen whose causes were grouped in 16 category groups: extra hours and reflexes, social charges, social benefits, additionals, retirement, fees, income, equalization, legal framework and affiliations, contract, damage, contributions and discounts, accident and disease, responsibility, stability and, finally, the remaining causes (See Annex 1 with the subcategories within each grouping).

At first, we replicated the previous exercise to the subsample where we identified the type of cause but still without segregating them. The estimation of equation 1 produces the results described in Table 5. In the observed subsample, the results are qualitatively similar with the exception of some specifications where 


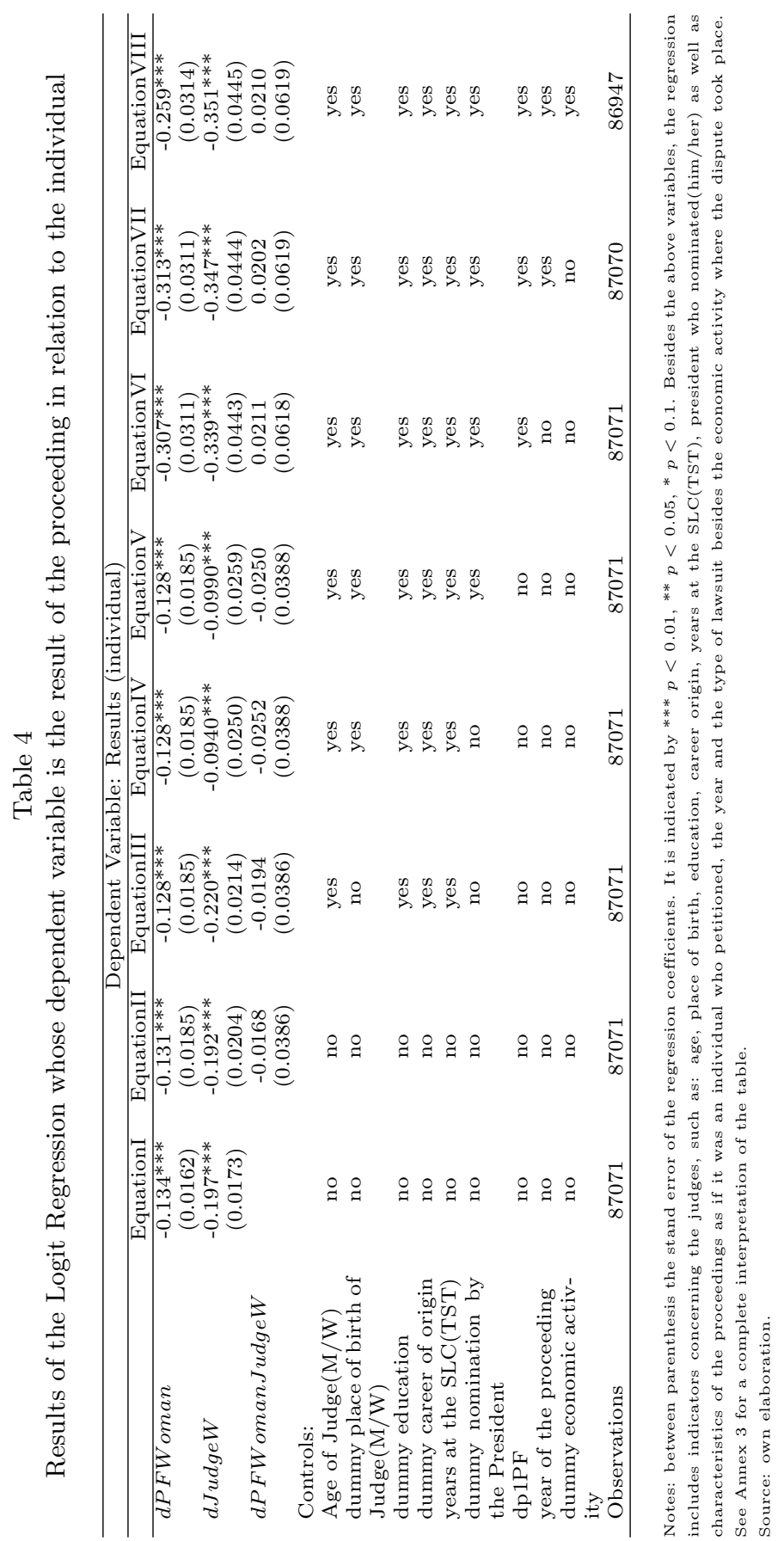


the interaction coefficients proved meaningful and positive.

Although the subsample is not fully representative since the interaction variable proves being significant as from equation VI (before the inclusion of the cause control), the regression Equation IX that includes the causes as controls presents a non-negligible increase within the magnitude of the estimated coefficient. This result is a good example that by controlling the causes, reducing, this way, the variability among the proceedings, we could find indicators that the female judges would tend to be more favorable to the female gender than the male and male judges would tend to be more favorable to the male gender than the female. That is, we noticed that it is positive and significant the ratio of the probability of female judges favor females comparatively to males relatively to the probability of male judge favoring males comparatively to females in this subsample.

However, the bias might occur solely in some cases, either in the ones where there is a higher ambiguity in the interpretation of the laws or in cases in which the legislation already governs heterogeneous rights between men and women. Thus, we stratified the subsample within the causes generating 16 different layers. Considering that in a proceeding the individuals may litigate for more than one issue, some proceedings were present in more than one layer.

The results of the estimations are described in Table 6 . The estimates indicate that if there is a gender bias in the SLC(TST) it is likely that it might occur during the disputes whose causes we classified as "equalization", "framing and affiliations" and "other causes". ${ }^{2}$

"Equalization" corresponds to the proceedings in which the equalization of rights, salaries and working hours among individuals are discussed. It happens when, in the worker's view, he performs the same task as other workers, but they avail of additional benefits not available to him. This equalization among workers may happen between workers of the same or different gender. "Framing and affiliations" embraces the functional and the labor union link as well as the recognition of an employment link between the parts. Finally, "other causes" stand for more bureaucratic issues such as missing the deadline, the non-completing or failure in submitting the necessary documents for continuing the proceeding so that, in this case, the lawsuit is prevented from continuing.

As to the first two categories, an attempt to resort to an equivalence between the genders seems intuitive. And, in these cases, there might be more room for different understandings among the men and women judges so that they become more explicit within the proceedings involving men and women. The third category ("other causes"), although less intuitive it is important because if there is the possibility of a bias evidence in the decisions given by men and women judges, perhaps it may occur just now amid the procedural meanders. In general, this question is more restrained to the characteristics of lawyers and defenders than actually the proceedings parties, but they bring about a bias channel.

${ }^{2}$ The classification of the causes in several categories is in Annex 1. 


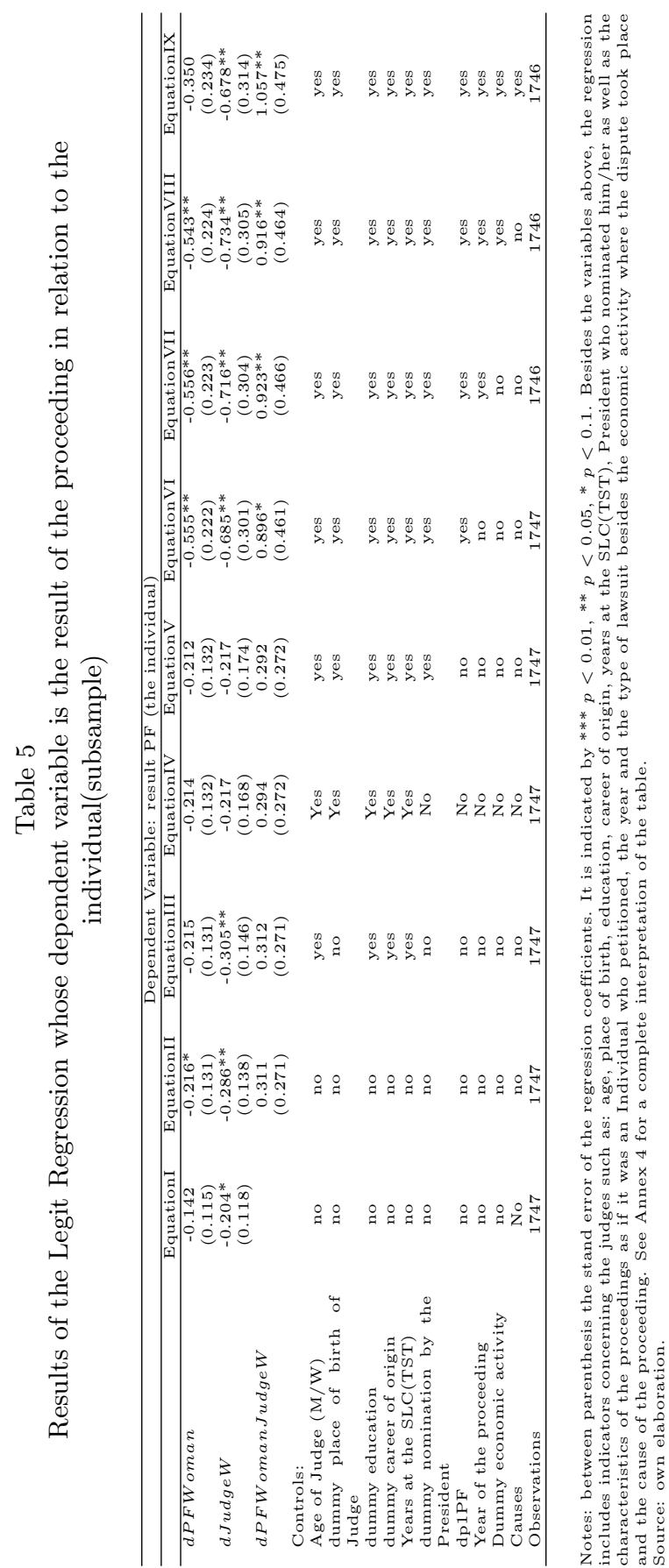

Brazilian Review of Econometrics 32(1) May 2012 


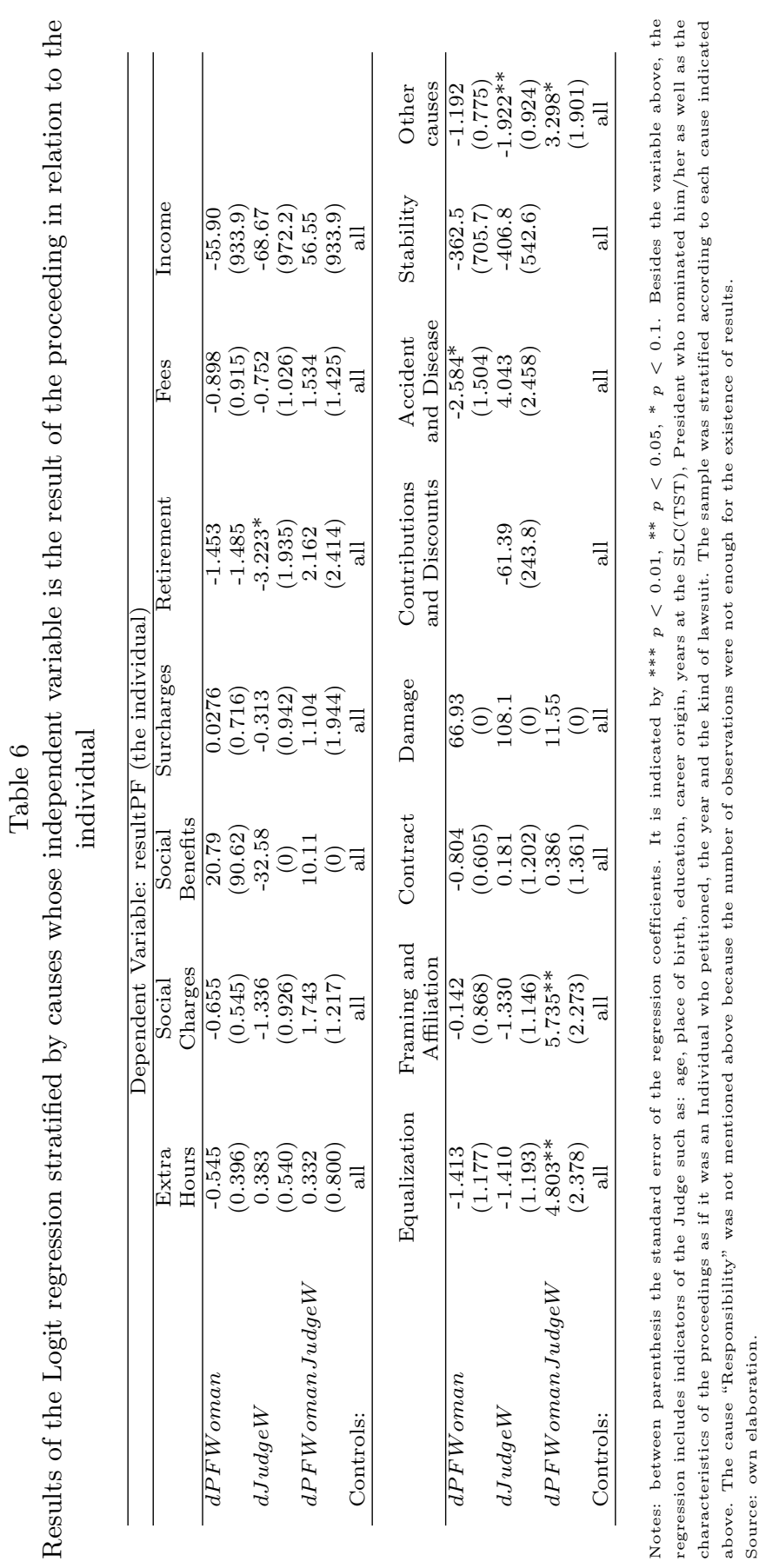




\section{Conclusion}

This is the first empirical work that makes use of legal proceedings of the Brazilian Superior Labor Court to establish the existence or not of a gender bias in the decisions given by the institution. We do that in a context where the proceedings are randomly distributed.

Our database comprehends information as to the parties' gender involved in the proceedings besides several traits concerning the judges. This study explores the proceedings randomization to identify the judge's gender effect over his/her decision concerning the proceedings of male and female individuals.

The evidence points to the fact that the Judges of the Superior Labor Court SLC(TST) tend to favor the individual (worker). Moreover, the fact that the individual involved in the proceeding belongs to the female gender decreases the individual's probability of winning. Although the results are quite robust within the different samples, they, in fact, do not represent a bias in the judiciary, since the judges may be strictly abiding by the laws given that perhaps the laws themselves are more prone to stand for the individual and the male gender.

Our results are not so clear as to a bias presence. By and large, the judges seem not to skew their decisions because of the gender of the people involved in the dispute, but, in some specific causes there is evidence that this movement might be happening. That is the case with "equalization", "framing and affiliation", and "other causes".

Thus, although we are not able to lead to decisive conclusions about the existence of gender bias within the Labor Justice, our results point to the existence, at least in some proceedings, of a gender bias within some of SLC(TST) decisions. That being so, in some specific causes, the women Judges are bent to favor the females; whereas the men judges are inclined to support the males what indicates that depending on the relative importance of these specific causes within the total number of disputes, the judiciary bias in favor of one of the genders may impact over the differentials within the Brazilian labor market. In the specific case, as there are much more male judges than female judges at the Superior Labor Court SLC(TST), the bias result would be against the female gender what would potentially lead to a mitigation in the salary differential between the genders if the employers anticipate such Brazilian labor judiciary behavior when negotiating their employees' salaries.

\section{References}

Albrecht, J., Björklund, A., \& Vroman, S. (2003). Is there a glass ceiling in Sweden? Journal of Labor Economics, 21:145-177.

Araújo, L. \& Ponczek, V. (2012). Informal wages in an economy with active labor courts. Technical report, FGV-EPGE. Mimeo. 
Bayard, K., Hellerstein, J., \& Neumark, D. (2003). New evidence on sex segregation and sex differences in wages from matched employee-employer data. Journal of Labor Economics, 21:887-922.

Bergmann, B. (2008). Basic income grants of the welfare state: Which better promotes gender equality? Basic Income Studies, 3:1-7.

Bertrand, M. \& Hallock, K. F. (2001). The gender gap in top corporate jobs. Industrial and Labor Relations Review, 55:3-21.

Blau, F. D., Ferber, M., \& Winkler, A. (2006). The Economics of Women, Men, and Work. Pearson Prentice Hall, Chicago, USA.

Blau, F. D. \& Kahn, L. M. (1997). Swimming upstream: Trends in the gender wage differential in the 1980s. Journal of Labor Economics, 15:1-42.

BRASIL (2004). Emenda Constitucional No 45. 30 de dezembro de 2004.

BRASIL (2008). Tribunal Superior do Trabalho (TST). Regimento Interno do Tribunal Superior do Trabalho. Brasília, Tribunal Superior do Trabalho.

Bryan, M. \& Sanz, A. (2007). Does housework lower wages and why? Evidence for Britain. Economics Series Working Papers 331, University of Oxford, Department of Economics.

Bucheli, M. \& Sanroman, G. (2005). Salarios femeninos en el Uruguay ¿Existe um techo de cristal? Revista de Economía, 12:63-88.

Chattopadhyay, R. \& Duflo, E. (2004). Women as policy makers: Evidence from a randomized policy experiment in India. Econometrica, 72:1409-1443.

Deloach, S. B. \& Hoffman, A. L. (2002). Russia's second shift: Is housework hurting women's wages? Atlantic Economic Journal, 30:422-432.

Easterlin, R. (1995). Preferences and prices in choice of career: The switch to business, 1972-87. Journal of Economic Behavior and Organization, 27:1-34.

Edwards, R. (2006). Maternity leave and the evidence for compensating wage differentials in Australia. Economic Record, 82:281-297.

Galarza, J., Medina, R., \& Díaz, L. (2006). Evolución de las diferencias salariales de género en seis países de América Latina. In Piras, C., editor, Mujeres $Y$ Trabajo en América Latina. Banco Interamericano de Desarrollo.

Gupta, S. \& Ash, M. (2008). Whose money, whose time? A nonparametric approach to modeling time spent on housework in the United States. Feminist Economics, 14:93-120. 
Heckman, J. J. \& Pagés, C. (2000). The cost of job security regulation: Evidence from Latin American labor markets. Working Paper 7773, NBER, Cambridge: United States. National Bureau of Economic Research.

Hersch, J. \& Stratton, L. S. (1994). Housework, wages, and the division of housework time for employed spouses. American Economic Review, 84:120-126.

Hersch, J. \& Stratton, L. S. (2002). Housework and wages. The Journal of Human Resources, 37:217-229.

Lundberg, S. (2008). Gender and household decision-making. In Bettio, F. \& Verashchagina, A., editors, Frontiers in the Economics of Gender. Routledge, New York, USA.

Álvares, B. \& Miles, D. (2006). Husbands' housework time: Does wives' paid employment make a difference? Investigaciones Económicas, 30:5-61.

Macpherson, D. \& Hirsch, B. (1995). Wages and gender composition: Why do women's jobs pay less? Journal of Labor Economics, 13:426-471.

Madalozzo, R. \& Martins, S. R. (2007). Gender wage gaps: Comparing the 80s, 90s and 00s in Brazil. Revista de Economia e Administração, 6:141-156.

Madalozzo, R., Martins, S. R., \& Shiratori, L. (2010). Participação no mercado de trabalho e no trabalho doméstico: Homens e mulheres têm condições iguais? Revista Estudos Feministas, 18:547-566.

Miller, P. (2009). The gender pay gap in the US: Does sector make a difference? Journal of Labor Research, 30:51-74.

Moe, K. (2003). Women, Family, and Work: Writings on the Economics of Gender. Blackwell Publishing.

Olivetti, C. \& Petrongolo, B. (2008). Gender gaps across countries and skills: Supply, demand and the industry structure. Working Paper 17349, NBER.

Waldfogel, J. (1998). Understanding the "family gap" in pay for women with children. Journal of Economic Perspectives, 12:137-157. 


\section{Annex 1: Classification of the Causes}

\begin{tabular}{ll}
\hline Extra Hours and Reflexes & $\begin{array}{l}\text { Extra Hours, intra and inter work schedule, weekly rest, overtime } \\
\text { bank. }\end{array}$ \\
Social Charges & Previous Notice, Unemployment Insurance, Vacation, 13th Salary, \\
& Holidays, Severance Pay Indemnity Fund(FGTS), Social Surcharges. \\
Social Benefits & Food Voucher, Sickness Benefit, Transportation Voucher, Health \\
& Plan, Funeral Grant, Life Insurance, Fuel and Telephone Allowance. \\
Surcharges & Sixth Part and the five-year period, Risk and Unhealthiness Pre- \\
& mium, night shift premium, constant academic improvement, trans- \\
& fer, seniority and bonus leave. \\
Retirement & Retirement, willful dismissal (PDV) encouraged dismissal (PDI), \\
& pension. \\
Fees & Free legal assistance, lawyers' fees, professional fees, procedural \\
& costs. \\
Income & Payment bonus, accumulative functions, career and salary plan, \\
& profit, variable commissions and remuneration, equalization, \\
& salaries differences and readjustments, working hours and rights \\
& equalization. \\
Equalization & Equalization differences and salaries readjustments, working hours \\
and rights equalization. & Functional and union framing, employment link, trust-holding po- \\
Framing and affiliation & sition. \\
Employment abandonment and reintegration, irregular hiring, dis- \\
Eontract & missal, justified dismissal, employment contract termination and \\
& extinction, contract amendment, moral and material damage. \\
Momages & Moral and material damages. \\
Labor union, assistance, social security contributions, discounts. \\
Accident
\end{tabular}




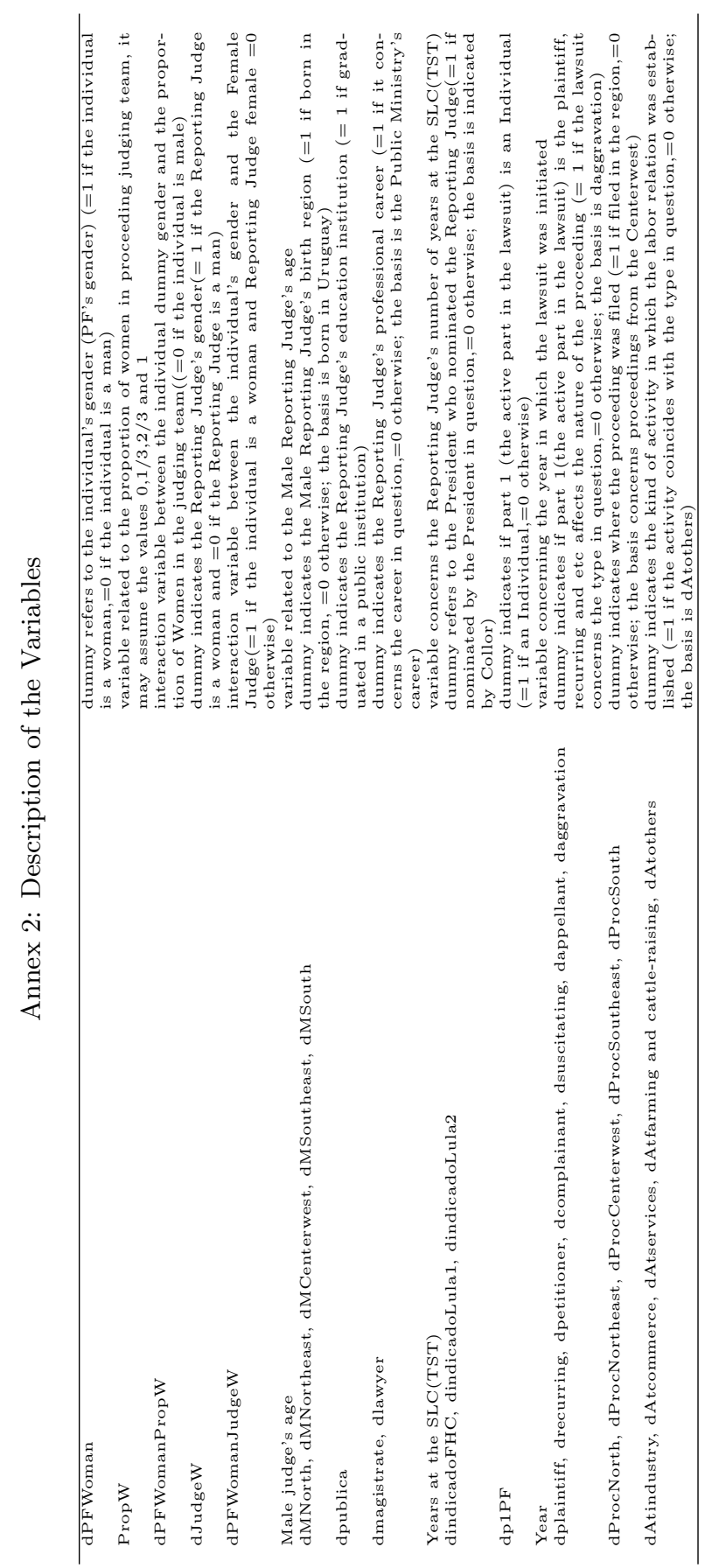

Brazilian Review of Econometrics 32(1) May 2012 


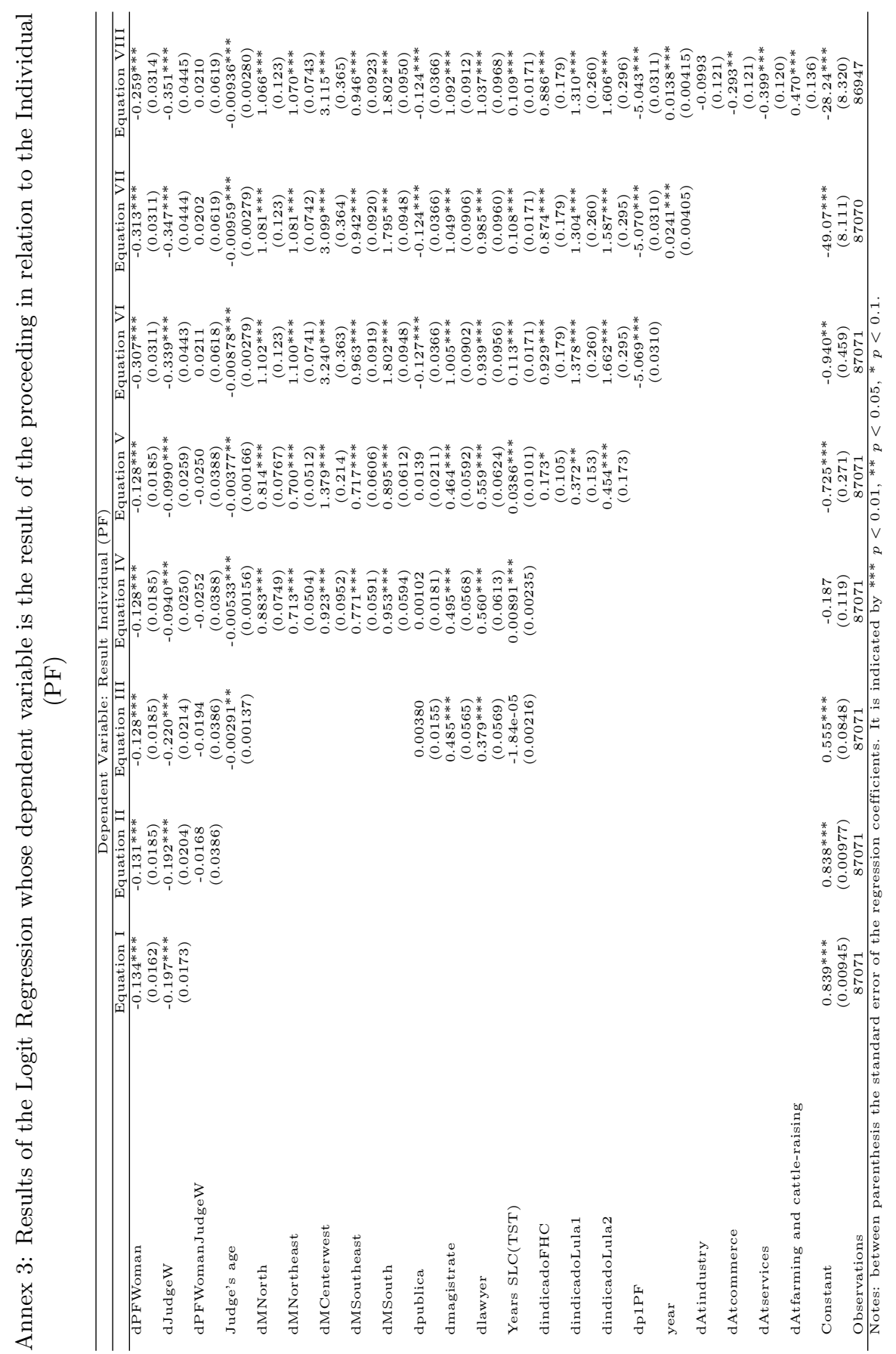




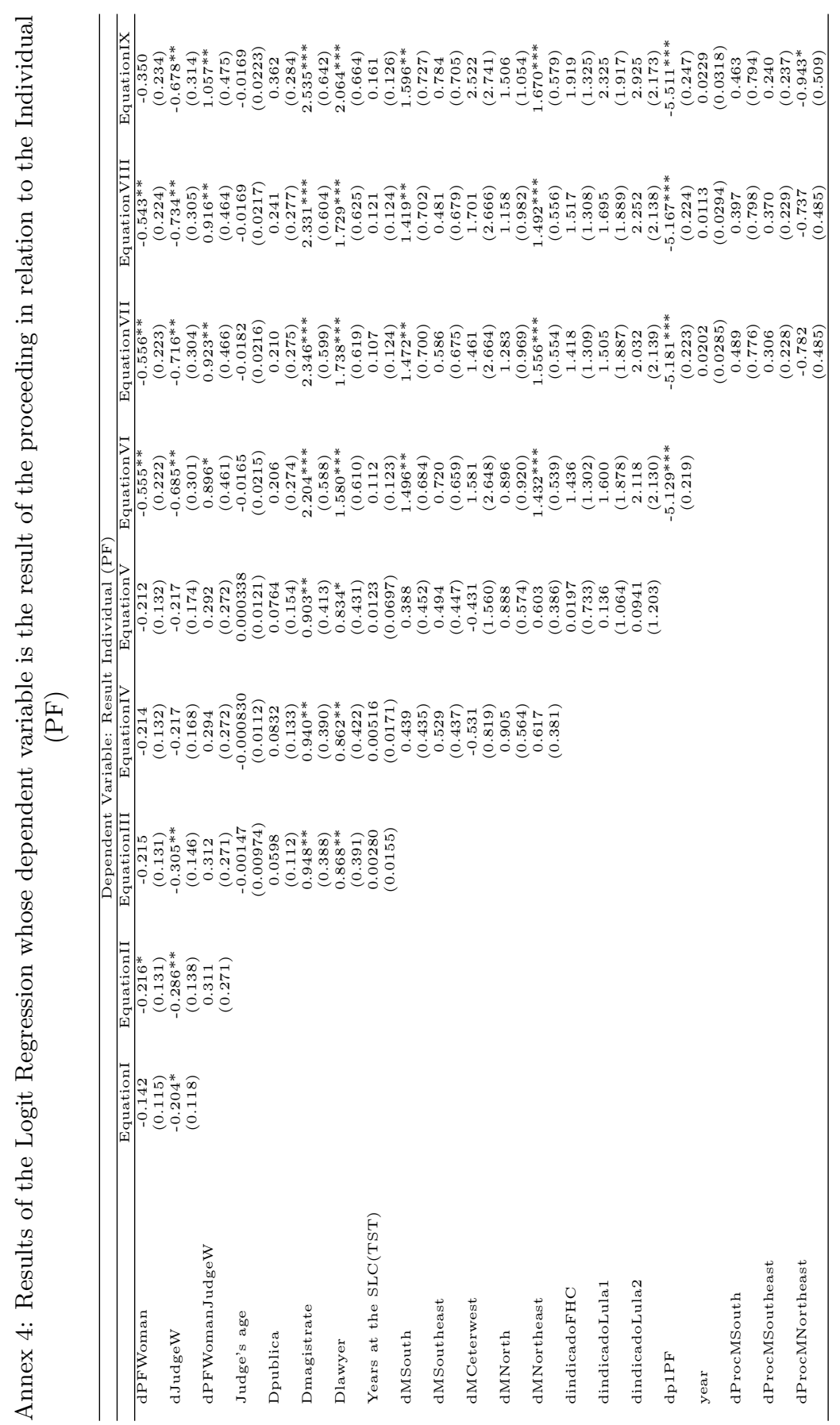




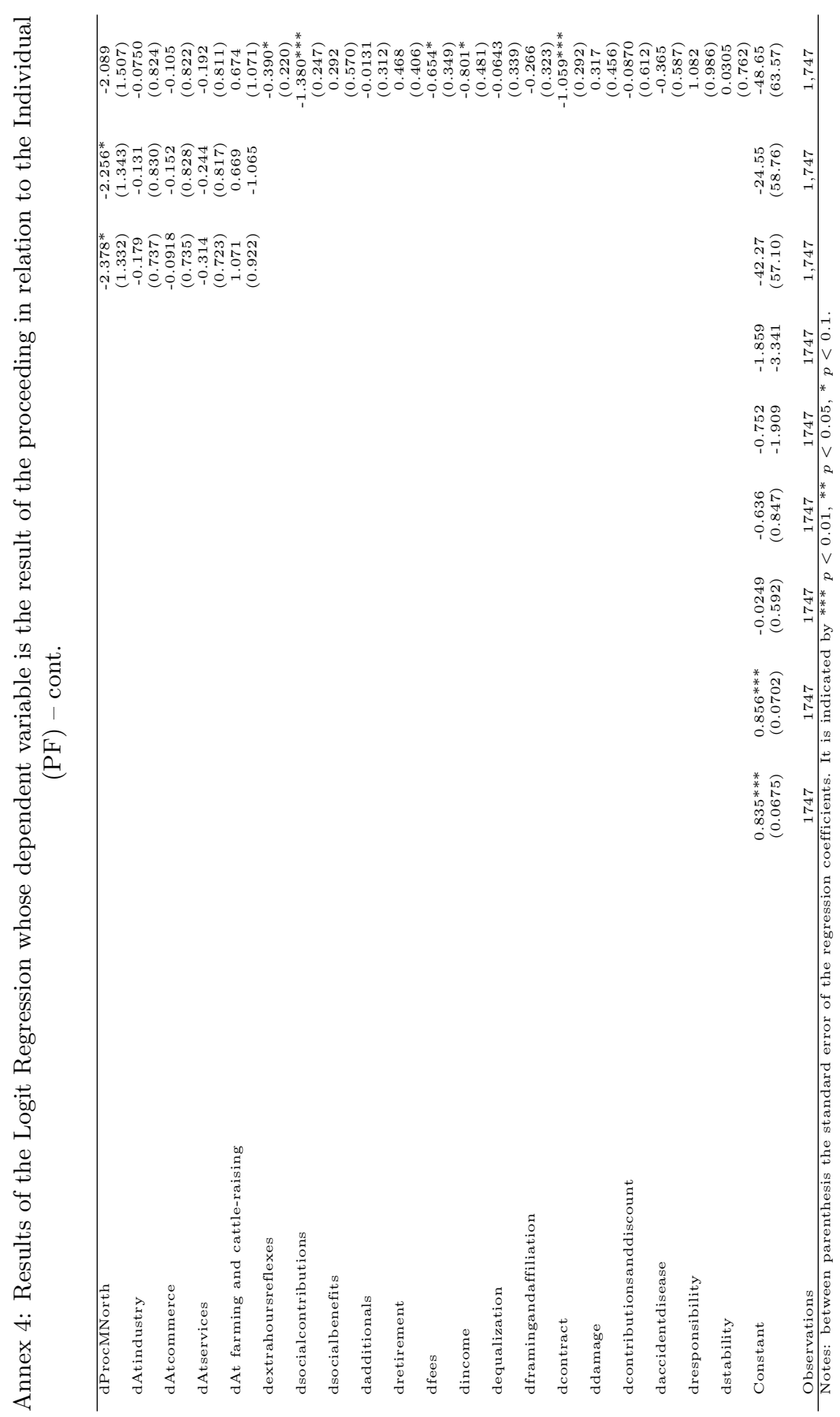

